\title{
Liability Structure in Small-Scale Finance: Evidence from a Natural Experiment
}

\section{Citation}

Carpena, Fenella, Shawn Cole, Jeremy Shapiro, and Bilal Zia. "Liability Structure in Small-Scale Finance: Evidence from a Natural Experiment." World Bank Economic Review 27, no. 3 (2013): 437-469. (Was Harvard Business School Working Paper, No. 13-018, August 2012.)

\section{Published Version}

https://doi.org/10.1093/wber/lhs031

\section{Permanent link}

http://nrs.harvard.edu/urn-3:HUL.InstRepos:9502858

\section{Terms of Use}

This article was downloaded from Harvard University's DASH repository, and is made available under the terms and conditions applicable to Open Access Policy Articles, as set forth at http:// nrs.harvard.edu/urn-3:HUL.InstRepos:dash.current.terms-of-use\#OAP

\section{Share Your Story}

The Harvard community has made this article openly available.

Please share how this access benefits you. Submit a story.

Accessibility 
H A R V A R D

\section{Liability Structure in Small- Scale Finance: Evidence from a Natural Experiment}

Fenella Carpena

Shawn Cole

Jeremy Shapiro

Bilal Zia

\section{Working Paper}

13-018

August 15, 2012 


\title{
Liability Structure in Small-Scale Finance: Evidence from a Natural Experiment
}

\author{
Fenella Carpena, Shawn Cole, Jeremy Shapiro, and Bilal Zia*
}

\begin{abstract}
Microfinance, the provision of small individual and business loans, has witnessed dramatic growth, reaching over 150 million borrowers worldwide. Much of its success has been attributed to overcoming the challenges of information asymmetries in uncollateralized lending. Yet, very little is known about the optimal contract structure of such loans - there is substantial variation across lenders, even within a particular setting. This paper exploits a plausibly exogenous change in the liability structure offered by a microfinance program in India, which shifted from individual to group liability lending. We find evidence that the lending model matters: for the same borrower, required monthly loan installments are 11 percent less likely to be missed under the group liability setting, relative to individual liability. In addition, compulsory savings deposits are 20 percent less likely to be missed under group liability contracts.
\end{abstract}

Word Count: 10,615

*UC Berkeley (fenella@econ.berkeley.edu), Harvard Business School (scole@hbs.edu), Yale University (jeremy.shapiro@yale.edu), and World Bank (bzia@worldbank.org), respectively. 


\section{Introduction}

Theory and evidence highlight financial market imperfections as a central cause of poverty and a key impediment to growth (Banerjee and Newman, 1993; Rajan and Zingales, 1998). In theories of capital accumulation for example, financial market imperfections influence the ability of the poor to borrow for investments in education and physical capital. Additionally, in models explaining entrepreneurship, information asymmetries and transaction costs prevent profitable entrepreneurial activities of the poor, who often have no collateral. Lack of access to financial services may thus play a crucial role in leaving many productive opportunities for the poor untapped, as well as in generating persistent income inequality and lower growth (Beck et al., 2007) . $^{1}$

Microfinance, the provision of credit, savings and other financial services to low-income households and entrepreneurs, has exploded in popularity and coverage in recent years, particularly in meeting the large unmet demand for finance (Morduch, 1999, Armendáriz de Aghion and Morduch, 2010). Emerging markets and developed economies alike, including the United States, now provide microfinance services through a variety of public and private channels. The growth of microfinance has been unprecedented: between 2004 and 2008, the sector's average annual asset growth rate was 39\%, reaching US $\$ 60$ billion in total assets by the end of 2008 (Chen et al., 2010). A careful evaluation of microfinance in Banerjee et al. (2009) also reveals that microcredit has important effects on business outcomes and the composition of household expenditure. The rapid growth of microfinance, along with its potential for promoting development, has attracted the interest not only of governments, donors, and socially oriented investors, but of mainstream commercial banks as well.

Perhaps the most celebrated feature of microfinance is the group liability contract, a lending methodology pioneered by the Grameen Bank in Bangladesh. Under this contract, loans without collateral are extended to a group of borrowers whose members are jointly liable for each other's repayment. Since groups form voluntarily and group members are responsible

\footnotetext{
${ }^{1}$ See World Bank (2008) for a literature summary.
} 
for paying off each other's debts, borrowers have the incentive to screen risky clients, monitor their peers, and enforce repayment. The success of this model with the Grameen Bank led to its replication in many countries around the world, with over 150 million individuals reached at the end of 2007 (Daley-Harris, 2009). This model is particularly important since small firms suffer most from institutional weakness (Beck et al., 2005), and because the structure of the banking sector can have important distributional impacts on growth (Cetorelli and Gambera, 2001).

While most microfinance organizations use group liability, not all do so. On the one hand, group liability may solve information asymmetry problems by leveraging social ties and the borrower's knowledge about the community, and may reduce monitoring costs to the lender by motivating borrowers to monitor each other. On the other hand, social sanctions may be limited, bad clients may free-ride on good clients, and borrower groups may collude against the lender. In addition to group liability lending, many microfinance programs also employ a variety of approaches to maintain high repayment rates. For example, some programs implement frequent repayment schedules, progressive lending, or require collateral substitutes. And yet, very little is known about the efficiency of such designs in ensuring repayment.

Indeed, the question of an optimal loan contract structure remains largely unanswered in both the theoretical and empirical microfinance literature. Theoretical studies have mainly focused on explaining how and why group liability mechanisms work, offering competing predictions on its benefits, while the empirical literature lags behind the theory. Two important exceptions are Giné and Karlan (2009) and Attanasio et al. (2011). Giné and Karlan (2009) reports on a field experiment in the Philippines to test the effect of individual versus group liability lending. Their analysis focuses on the importance of peer monitoring, and finds no significant difference in default among individual and group borrowers. While Giné and Karlan identify the effects of peer monitoring, they do not focus on the effects of joint liability. In contrast, our paper examines the effect of contract structure on the group of 
borrowers who are willing to borrow with either individual or group liability. Attanasio et al. (2011), on the other hand, conduct a field experiment in Mongolia in which villages were randomly assigned to obtain access to group loans, individual loans, or no loans. The main objective of Attanasio et al. (2011) is to measure the impact of both types of microcredit on different poverty measures. The authors find a positive impact of group liability loans on food consumption and entrepreneurship, with no difference in repayment rates between individual and group liability.

Identifying the impact of group liability on outcomes such as default rate is complicated by the standard problems of selection and omitted variables bias. Individuals with different financial habits might choose to take one form of contract but not the other. Alternatively, lenders with different levels of sophistication may attract different client mixes, and offer different contracts. One cannot simply compare clients across lending contracts, since selfselection or other aspects of the program may be the root cause of any observed differences.

In this paper, we use a natural experiment to compare loan repayment and savings discipline between individual and group lending models.2 In this setting, group lending differs from individual lending in both the liability structure, and the repayment practices. In group lending, borrowers are liable for the scheduled payments of the group members, and the loan officer interacts primarily with the group leader, who collects payments from other group members, whereas under individual lending, borrowers are personally liable and interact directly with the loan officer. Our empirical strategy takes advantage of a change in lending policies of Saath, a non-government organization providing microfinance services in India. Saath switched from individual to group lending. This transition was governed by a strict policy rule: after a particular date, all borrowers completing an individual liability cycle were subsequently offered a group liability loan in their next loan cycle. Individual liability loan completion dates were distributed relatively uniformly throughout the year, offering a natural variation in the timing of loan contract transitions. Thus, in July for

\footnotetext{
${ }^{2}$ Throughout this paper, we use the terms "group liability" and "joint liability" interchangeably.
} 
example, individual liability borrowers finishing a loan cycle would switch to group liability in the following loan, while those whose loan cycle ended after July would remain under an individual contract setting until the end of their cycle. This plausibly exogenous change, phased in over time, generates natural control groups, and allows us to credibly identify the causal impact of group liability structure, in what amounts to a repeated difference-indifference framework. At any particular point in time, our "treatment" group then consists of clients who have fully repaid their individual liability loan and currently have a group liability loan, while our "control" group consists of individual liability loan clients who will eventually convert to a group liability loan.

Our main analysis focuses on loan performance and estimates the effect of group liability on such outcomes. We find that group liability structure significantly improves repayment rates. In particular, clients are about $11 \%$ less likely to miss a monthly repayment in the group liability setting relative to individual liability; this effect holds even with individual fixed effects. We also find that there is greater discipline in monthly compulsory savings deposits when clients have a group liability loan. Specifically, compulsory deposits are about $20 \%$ less likely to be missed in the group liability setting. Our results provide the first credible evidence that group liability contracts improve upon individual liability, particularly in ensuring repayment and increasing savings discipline among clients.

These results, however, are also subject to some important caveats. First, the transition to group liability lending was accompanied by other changes to the lending structure, particularly an increase in loan size, which may have raised the continuation value of borrowing. Nevertheless, we argue that our estimates of the impact of the change in lending model may be lower bounds. Second, since our empirical strategy focuses on clients who chose to borrow under both individual and group liability settings, the external validity of our results may be limited. Third, limitations in data availability preclude us from examining loan outcomes such as delinquency or prepayments. Finally, our empirical strategy does not allow us to test for the specific mechanisms by which group lending improves repayment. Based on 
our discussions with Saath, interviews of field officers, and our reading of the evidence, we speculate that "peer pressure" was the mechanism at work. We discuss these caveats further in Section 5.2

From a practical and policy perspective, our results are quite timely. Microlenders worldwide are increasingly weakening joint liability in their lending approaches Armendáriz de Aghion and Morduch, 2010). BancoSol in Bolivia has shifted significant proportions of its lending portfolio from group to individual lending, and even the Grameen Bank has moderated its joint liability clause, allowing defaulters to get back on track without invoking group pressure. Our results therefore suggest a cautionary tale for microfinance. Many MFIs are now moving away from joint to individual liability, but even so, this transition is not supported by strong empirical evidence. This finding is important, since to our knowledge, only two other papers examine the relative merits of joint and individual liability contracts; our paper underscores the fact that more research is required to provide better policy guidance for MFI practitioners worldwide.

The rest of this paper is organized as follows. Section 2 reviews the existing literature

on liability structure in microfinance. Section 3 provides a background on the microfinance program we study, as well as the change in liability structure of its loan products. In Section 4. we provide a description of the data and summary statistics. We discuss our empirical strategy and results in Section 5 . Finally, Section 6 concludes.

\section{Predictions of Group Liability}

A wealth of theoretical literature in microfinance explores the mechanisms behind group liability contracts, particularly on mitigating information asymmetries and enforcement problems. Stiglitz (1990) shows that the group liability structure overcomes ex ante moral hazard, since it creates incentives for group members to monitor each other's loans. Similarly, Banerjee et al. (1994) study credit cooperatives and underscore the role of peer monitoring. They 
describe a model where higher monitoring results in higher borrower effort, and hence, a higher probability of project success.

Even if a project succeeds, however, borrowers may refuse to repay or may claim that the project failed to avoid repayment. Such strategic default is also captured in several theoretical studies on group liability. For example, Besley and Coate (1995) provide a model demonstrating that joint liability may harness social capital to increase a borrower's willingness to repay. Armendáriz de Aghion (1999) likewise demonstrates that joint liability agreements may reduce the incidence of strategic default since borrowers may impose social sanctions on the defaulter.

In addition to examining moral hazard, the theoretical literature investigates how joint liability mitigates adverse selection. Ghatak (2000) describes a model under a scenario where borrowers have ex-ante information about the riskiness of other borrower's investment projects, while lenders do not. Joint liability then acts as a screening device inducing "assortative matching." Specifically, borrowers with safe investments will partner with other safe borrowers, leaving risky borrowers to form groups with themselves.

These theoretical models, among others, have shown that group liability may improve repayment rates by alleviating imperfections in the credit market. However, whether group liability outperforms other contract structures remains an open question in the microfinance literature. For example, Besley and Coate (1995) point out in their model that if borrowers cannot repay as a group, then some group members will not find it worthwhile to contribute their share of repayment, even though they would have repaid under individual lending.

Inconclusive empirical evidence accompanies these ambiguous theoretical predictions. Some empirical studies support the theoretical advantages of group liability. For instance, in Bangladesh, Sharma and Zeller (1997) show that groups that were formed through selfselection had better repayment rates; however, this study may suffer from omitted variable biases. Other studies provide little empirical support for the theory. For example, Ahlin and Townsend (2007) use Thai data to show that repayment rates are negatively associated with 
social ties.

Only a handful of studies examine the merits of group liability relative to other contract structures. Fischer (2010) conducts a series of lab experiments with actual microfinance clients and provides evidence that contract structure affects project selection. Specifically, he finds that group liability increases risk-taking, relative to individual liability contracts, as borrowers free-ride on the insurance provided by their partners. In a randomized experiment in India where borrowers were assigned to either weekly or monthly repayment meetings, Feigenberg et al. (2010) find that more frequent repayment meetings build social capital among borrowers, which in turn leads to reduced default.

The most relevant study on repayment rates under different loan liability structures are Giné and Karlan (2009) and Attanasio et al. (2011). Giné and Karlan (2009) reports evidence from two field experiments in the Philippines. In the first, borrowers who had signed up under a group liability structure were converted to individual liability. Since both joint and individual liability groups previously underwent the same screening, the authors can independently identify the peer monitoring effect under group liability. However, they cannot identify or rule out any impact of screening with this methodology. In addition, the group repayment and monitoring mechanisms may already be entrenched and difficult to undo even with an individual liability structure. Their second experiment randomly introduced either group or individual liability lending to new borrowers. However, the experiment was conducted at the loan center level and take-up was quite uneven between group and individual loan centers, resulting in potential statistical power concerns. In both instances, they find default rates are invariant to contract structure.

Attanasio et al. (2011) conduct a field experiment in Mongolia where villages were randomly assigned to group loans, individual loans, or no loans. The authors seek to measure the impact of individual and group loans on reducing poverty. In particular, the study finds that clients who received group loans had higher food consumption and were more likely to operate a business than control villages. Clients in individual-lending villages had no 
significant increases on any of these measures. On repayment outcomes, the authors find no significant differences in repayment rates between individual and group liability.

While loan default and repayment are the primary outcomes of interest when examining group liability contracts, the economics literature on rotating savings and credit organizations (Roscas) suggests that group liability may also have positive effects on savings. Bouman (1995) argues that participating in credit and savings groups allows individuals to avoid demands of financial support from their relatives, since contributions to a Rosca are generally recognized by society as a senior claim. In a theoretical model, Ambec and Treich (2007) show that Roscas may serve as a commitment device which helps people overcome selfcontrol problems. Gugerty (2007) provides support for this model, reporting that many Rosca participants in rural Kenya cite "you can't save alone" or "sitting with other members helps you to save" as their primary motivation for participating in a Rosca.

Our paper complements Giné and Karlan (2009) by examining optimal contract structure in an alternative setting. While the original experiment in Giné and Karlan $(2009)$ focuses on moving from group to individual liability contracts, we explore the reverse; that is, the shift from individual to group liability. The following section describes the setting and our empirical strategy in more detail.

\section{Empirical Setting}

Our partner institution, Saath, is a non-government organization based in Ahmedabad, India. Founded in 1989, Saath implements development initiatives in slum communities, including health, infrastructure improvement, and livelihood training programs. Additionally, Saath provides credit and savings services to the urban poor through its Microfinance Unit. In 2009, Saath Microfinance had over 6,400 active clients in 4 branches, with a savings portfolio of INR 18 million (USD 390,000) and a loan portfolio of INR 19 million (USD 410,000) $!^{3}$

While Saath has provided mentoring support to community-based credit and savings

\footnotetext{
${ }^{3}$ Based on Saath's 2008-2009 Annual Report.
} 
groups since the mid-1990s, its Microfinance Unit was not formally established until 2002. In that year, Saath integrated these credit and savings groups into its organization, as well as registered them as cooperative societies with the Indian government. Saath also began managing these credit and savings cooperatives at this time, giving way to the Saath Microfinance Unit. Today, Saath Microfinance provides various financial services to slum communities, including voluntary savings accounts, compulsory savings accounts, and group liability loans.

\subsection{Savings Products}

Since its inception in 2002, Saath Microfinance has been offering voluntary savings accounts to its clients. These voluntary savings earn an interest of $6 \%$ per year and do not have a minimum balance. As the name suggests, members are not obliged to make regular deposits in voluntary savings accounts. Any amount may be deposited, but only six withdrawals per year may be made.

In November 2007, Saath Microfinance initiated compulsory savings accounts among its members. Specifically, members are required to deposit INR 100 (USD 2) every month into compulsory savings accounts, for the duration of their membership with Saath Microfinance. Clients may withdraw any amount from their compulsory savings at any time, as long as a minimum balance of INR 3,500 (USD 70) is maintained. Similar to voluntary savings, compulsory savings earn an interest of $6 \%$ per year. Any amount which the client deposits over the compulsory savings of INR 100 is deposited in the client's voluntary savings account. The goal of the compulsory savings account is to allow clients to build a financial buffer stock against adverse shocks, and to provide low-cost capital to Saath. These compulsory deposits were mandated of all borrowers, independent of the switch to group liability loans. Hence, all outstanding loans under both individual and group liability were required to make compulsory deposits after November 2007. In Section 5, we compare the adherence to these compulsory deposits for the same person as she moves from individual to group liability. 


\subsection{Loan Products}

In addition to savings products, Saath Microfinance provides loans for asset creation (e.g. house repairs), production (e.g. business working capital), and consumption (e.g. health, social functions). From its beginnings in 2002 until November 2007, Saath provided credit through individual liability loans. Beginning in November 2007, Saath discontinued individual liability loans, offering instead group liability loans to members applying for credit.

Under the individual liability loan model, a client was required to have been a member of Saath for at least six months with a savings account in order to be eligible for a loan. Members could borrow up to three times their savings account balance, at an interest rate of $18 \%$ per year $4^{\mathbb{4}}$ These individual-liability loans generally require no collateral; however, each loan applicant must meet two requirements. First, the loan applicant must have two "guarantors" who also have a savings account with Saath. Second, the combined savings balances of the loan applicant and the two guarantors must be greater than or equal to the loan amount applied for. Although guarantors are in principle required to maintain these savings balances through the duration of the loan, in practice this rule was not strictly enforced. Guarantors are not eligible for a loan until the loan they guaranteed has been fully repaid, but loan repayment is the sole responsibility of the borrower. Borrowers are required to make monthly installments which cover principal and interest. The monthly principal installment is a fixed amount, and since the interest rate is declining balance, the total installment amount (principal plus interest) varies every month. If the borrower defaults, Saath reserves the right to seize the borrower's savings, and if this amount is not enough to cover the loan, Saath reserves the right to take the guarantor's savings as well. However, in practice, as an NGO whose mission is to empower the poor, Saath never seized any of its individual borrowers' or guarantors' savings.

\footnotetext{
${ }^{4}$ Microfinance organizations typically quote interest rates in one of two forms: "declining," the standard used in developed markets, where the amount of interest due each period is calculated based on the interest rate and the remaining principal, and "flat," where the interest payments are calculated using the original principal amount. Thus a 10\% "flat" rate is significantly higher than a $10 \%$ "declining" rate. Saath quotes rates using the standard declining balance approach.
} 
With the group liability model, on the other hand, Saath extends credit to groups of individuals at an interest rate of $24 \%$ per year. Four loan size categories are available to clients: (1) Rs. 3,000-5,000, (2) Rs. 6,000-10,000, (3) Rs. 11,000-20,000, and (4) Rs. 21,00030,000. These groups form primarily through self-selection with joint applications submitted to Saath. Groups are composed of three to six individuals, all of whom must be Saath Microfinance members. Within each group, several criteria must be fulfilled. First, at least $50 \%$ of the group must have been Saath Microfinance members for at least 6 months with at least a savings account. Second, at least 50\% of the group must be female. Third, relatives or individuals from the same household are not allowed in the same group. And finally, loan terms must be homogenous across group members; that is, the number of installments as well as the monthly installment due dates must be the same, and the loan amount must not vary widely within each group. As in the individual liability model, group liability borrowers are required to make monthly installments for both principal and interest, although in this setting, total installment amounts (principal plus interest) are equated every month. (In the individual liability model, the monthly principal installment repayment was fixed, but the interest and therefore installment size varied each month.) Before any loans are disbursed, group members are also required to sign a "mutual agreement form," stating that they are liable to pay each other's debt in the event of default or delinquency. Borrower groups who have defaulted or are delinquent are no longer eligible to receive another loan from Saath.

\subsection{Shift from Individual to Group Liability}

Saath's decision to shift from offering individual liability to group liability loans in November 2007 was due to a change in the management's priorities. Saath wanted to lend to more people, provide larger loan amounts, and expand its microfinance operations geographically, but its lending activities had become stagnant under the individual liability model. In particular, the "guarantors" requirement for individual liability loans restricted credit eligibility, as Saath had already reached a point where almost all of its members were either borrowers 
or guarantors. Additionally, savings clients were reluctant to stand as guarantors for another client's loans, and loan amounts were limited to 3 times the total savings account balance of the borrower. Saath management thus shifted to group liability loans to overcome the restrictions in its individual liability model. In terms of the models discussed above, the limited ability of Saath members to pledge savings as a collateral prevented Saath from expanding, and it saw group liability as a way to solve this problem. In the year following this change, Saath gained almost 800 new clients and increased its reach from 11 to 20 wards.

The transition from individual liability to group liability loans was implemented with the following rule. Beginning in November 2007, all new loans disbursed were group liability loans; Saath would no longer disburse individual liability loans. However, existing loans whose term lasted beyond November 2007 were unaffected. For example, individual liability loan clients who completed their loan in February 2008 continued under the individual liability contract until then, and following February 2008 would receive a group liability loan should they borrow again. The date of switching from individual to group liability was therefore determined by individual liability loan completion dates. These completion dates and subsequent conversion to group liability loans were distributed relatively uniformly throughout the year.

Although Saath's loan product moved from individual to group liability beginning in late 2007, the location where repayments are made, the frequency of loan repayment collection, and the salaries for field officers remained similar across time in our dataset. An empirical concern for the analysis to follow is whether Saath's policy shift from individual to joint liability was also accompanied by a shift in their loan collection techniques. In June 2010, we conducted a short interview of Saath field officers regarding repayment collection. We were able to interview 10 out of the 12 Saath field officers who collected repayment among the sample of clients we study, while the remaining field officers are no longer with Saath. Results from this survey confirms that the location and frequency of loan repayments remained the same across the two settings; specifically, for both individual and group liability loans, we 
find that field officers collected repayment at the client's household, every month, $100 \%$ of the time. Additionally, $90 \%$ of the time under both regimes, the lender turned down future loan requests by defaulting clients.

For group liability borrowers, Saath does not require groups to designate one of its members as a "group leader," but in practice, all groups have a leader who is in charge of collecting repayments from other members. Hence, among individual borrowers, field officers visited each borrower, while among group borrowers, field officers typically visit only the group leader's household. If any member of a particular borrower group fails to make a scheduled payment, the field officer assembles all group members together and collects the installment amount from the other members as stipulated in the group liability contract. Both individual liability borrowers and joint liability borrower groups in default are not granted any loans in the future. In addition, over the period we study, there was no change in wages among field officers, who continued to receive a fixed monthly sum.5

In summary, borrowing conditions changed in the following ways: (1) borrowers were obliged to enter joint liability lending groups, rather than borrowing on their own from Saath; (2) the loan officers collected repayment from the group leader, rather than from each individual borrower; (3) monthly installments became fixed, rather than varying, and (4) the interest rate increased from $18 \%$ to $24 \%$. Given that multiple dimensions of the contract structure were changing, we discuss the implications of each of these changes on our analysis in Section 5.2 .

\section{Data Collection and Summary Statistics}

In this study, we use data from Saath Microfinance's administrative software systems. The loan data cover outstanding loans every month from April 2005 through March 2009. Since the change in the type of loan contract occurred in November 2007, the data contain over

\footnotetext{
${ }^{5}$ After March 2009 field officers received 1\% of the loan interest they collect. Surveys of field officers indicate that they were not aware of this change in compensation structure before it occurred. Nevertheless, to isolate the focus of our study on contract structure, we exclude months after March 2009 in the analysis.
} 
two years of monthly data on individual liability loans and over one year on group liability loans. Data are available electronically from only 2 out of 4 Saath Microfinance branches, Behrampura and Vasna, and we focus on these. They are the two largest branches, and the oldest, accounting for the vast majority of Saath's clients.

The data were maintained for accounting purposes, recording cash flowing in and out of each branch. They are therefore of very high quality. They do not, however, contain information on the terms of each loan, such as maturity dates, installment amounts, and amounts outstanding. These data were recorded by loan officers in client passbooks and administrative ledgers. As a result, we are unable to look at overdue amounts, prepayments, and other similar measures 6

While the data on loans cover April 2005 to March 2009, the savings data were only available from January 2008 to March 2009. The savings data include monthly aggregate deposit and withdrawal amounts, for compulsory savings accounts.

As previously described, in our main analysis we study borrowers who have received both individual and group liability loans to overcome the selection problem. Hence, in our dataset, these clients begin with an individual liability loan, and after November 2007, receive a group liability loan. Within Saath's Behrampura and Vasna locations, we find a sample of 276 such clients, representing $22 \%$ of the loan client base in these two branches as of March 2009 .

Table 1 provides summary statistics for our sample. Collectively, these clients received a total of 748 loans from Saath, of which 450 are individual liability loans and 298 are group liability loans. The average individual liability loan amount is about INR 10,000 (USD 220), and about INR 18,000 (USD 390) for group liability loans. Figure 1 plots the number

\footnotetext{
${ }^{6}$ The loan data come from three software systems which Saath Microfinance has used at different points in time. Each of the two branches in our dataset used a separate system until early 2008, when the current system was introduced in both branches. Because client identifiers were not carried over from one software system to another, we had to rely on using client names to track individuals over time. These names were unique since they included first, middle, and last names. In identifying clients across systems, $80 \%$ of the clients had exact name matches, while $14 \%$ had to be matched by hand due to name spelling errors. The remaining $6 \%$, on the other hand, could not be matched to the current software system. It is likely that these clients have withdrawn their membership with Saath Microfinance and therefore have not borrowed under the group liability setting, since Saath migrated information from the previous to the current software system only for existing members.
} 
of group liability loans that are disbursed over time. As the figure shows, the borrowers in our sample, all of whom received individual liability loans, switched to group liability loans at varying months. Our empirical strategy takes advantage of this staggered timing, comparing individual liability loan clients who have already received group liability loans to future recipients, to identify the impact of group liability on loan repayment behavior and savings discipline.

\section{$5 \quad$ Empirical Strategy and Analysis}

\subsection{Empirical Strategy}

To study the effect of contract structure on lending outcomes, we exploit the natural experiment provided by Saath's change in policy. The presence of an exogenous policy change is important. Without exogenous variation, it would be very difficult to know whether differences in outcomes were attributable to contract structure or to any number of other unobservable characteristics of borrowers or lending institutions. Indeed, theory predicts that different contracts will be optimal for different types of borrowers.

To overcome the selection problem, we focus our attention on borrowers of Saath who

received both individual and group liability loans. We exploit the natural phasing-in of group liability, in what amounts to a repeated difference-in-difference framework. At any particular point in time, our "treatment" group then consists of clients who have fully repaid their individual liability loan and currently have a group liability loan, while our "control" group consists of individual liability loan clients who will eventually convert to a group liability loan. Specifically, we estimate the following equation:

$$
y_{i l t}=\alpha+\beta T_{i l}+\gamma_{i}+\delta_{t}+\epsilon_{i l t}
$$

where the subscript $i$ refers to individuals, $l$ refers to loans, and $t$ refers to months. $T$ is 
a dummy variable equal to 1 if loan $l$ of client $i$ is a group liability loan, and 0 if it is an individual liability loan. $y_{i l t}$ is a measure of loan repayment or savings discipline. The estimate of $\beta$ then provides the effect of switching to group liability loans for individuals who are already borrowing. We include time effects $\delta_{t}$ since conversion to group liability loans was staggered across individuals, and the individual fixed effects $\gamma_{i}$ absorb time-invariant characteristics of each borrower.

\subsection{Limitations}

In what follows, we note some features of our setting which may limit the generalizability of the empirical results.

\subsubsection{Concurrent Changes in Loan and Savings Products}

As discussed in Section 3.3, the shift from individual to group liability lending contracts was accompanied by other changes in contract features. Specifically, in the group liability setting, the loan officers collected repayment from the group leader, rather than from each individual borrower; monthly installments became fixed, rather than varying; and the interest

rate increased from $18 \%$ to $24 \%$. Furthermore, simultaneous with the change to joint liability loan products, savings rules shifted as well, since Saath began requiring all of its members to keep compulsory savings accounts.

In our view, an ideal experimental evaluation would have included (1) obliging borrowers to enter joint liability lending groups, rather than borrowing on their own, and (2) loan officers collecting repayment from the group leader, rather than from each individual borrower, and would have left installment sizes and the interest rate fixed. Group lending contracts offered by the majority of MFIs in India collect repayment either from one person-an assigned leader - or from every borrower in the group at the same time. Hence, the change in mode of payment, we believe, is a feature of the group liability contract.

While the interest rate change and the change in monthly installments are not typical, our 
regression coefficients estimating the impact of the contract change are likely lower bounds. The increase in interest rate could in theory have several effects: a price effect might reduce demand, while the higher interest rate could increase repayment burden and induce default. Most evidence suggests microfinance borrowers are not very price elastic, so we are not too concerned about demand effects. The increase in interest rate should bias us against a finding that joint liability lending reduces default. Furthermore, our empirical analysis only considers individuals who borrowed under both the individual and group liability regimes, thus accounting for any self-screening among clients based on the increase in interest rates between the two loan contracts.

The change in monthly repayment installments and mode of payment also bears further discussion. The repayment schedule for individual liability loans required fixed principal repayments, along with interest. Hence, the nominal size of the monthly payments declined over the cycle of the loan. In contrast, the group liability repayment structure is based on a fixed monthly repayment throughout the term of the loan. Since our analysis focuses on the shift from individual to joint liability loans for the same person, for the same loan amount we are picking up the effect of a lower payment under individual liability (since the borrower is at the end of her loan cycle) vs. a relatively higher fixed payment under joint liability. This should bias us against finding a reduction in default. This bias effect is likely even greater in our case because the average loan size and corresponding repayment installment size is higher under joint liability.

The mode of payment also shifted under the individual and group liability settings. In the former, the field officer visited each individual liability borrower to collect repayment, while in the latter, the field officer only visited the group leader, who is in charge of collecting repayment from the other members. Nevertheless, this change in the mode of payment is a feature of group lending, since in the setting we study, group liability is a lending contract which involves both joint repayment to a group leader and joint liability. Thus, the "group" features, such as repayment to a group leader, may lower default, while the higher interest 
rates may increase default, so the effect we capture may well be a lower bound.

Saath's savings products also changed during our study period, as discussed in Section 3.1. However, we note first that in our main analysis on loan repayment and savings discipline, we focus only on individuals who converted to group liability loans, exploiting the timing of their switch. Doing so allows us to control for any changes that occurred at the microfinance institution level under the two loan contract regimes. In the context of the MFI-wide change in savings requirements, we are in other words comparing a shift from individual to joint liability for the same person (when we include individual fixed effects) facing mandatory savings under both liability structures. Since our empirical strategy rests on the continuous, rolling changeover from individual to joint liability after the announcement, our sample consists of borrowers who are opening and maintaining mandatory savings accounts prior to shifting to a joint liability loan. While the introduction of a mandatory savings account may have influenced the composition of borrowers, the internal validity of our results remain unaffected, since our analysis considers only those individuals who chose to renew their loans with Saath.

Theoretically, the imposition of mandatory savings could have two opposing effects: (a) it could discourage borrowers from renewing their loans since the real cost of borrowing has gone up with the imposition of a mandatory savings plan; or (b) it could encourage borrowers to renew their loans as individuals appreciate the saving discipline that compulsory accounts provide. This latter point is not trivial. Individuals may fail to save enough because they consistently put off savings to their future selves (Laibson, 1997), may be tempted to spend on immediate consumption (Banerjee and Mullainathan, 2010), or may face intra-household constraints (Ashraf et al., 2010). In a recent field experiment, Atkinson et al. (2010) find that prompting individuals to save at the time of loan repayment doubles the amount of savings.

The overall effect of mandatory savings on borrower selection is therefore ambiguous, and unfortunately we lack any household level data to be able to empirically differentiate 
these effects. In addition, we only have basic socioeconomic data from Saath records for clients who eventually joined joint liability groups. Nevertheless, we run a simple regression of renewal on percentage payments missed and find a strong statistically significant negative coefficient. Hence, clearly, there is screening based on past loan performance. However, we also find that this screening happened even for previous individual-to-individual renewals, and therefore cannot be considered an effect of joint liability or mandatory savings.

\subsubsection{External Validity}

Our study sample consists of individual borrowers who have repaid their individual loan and choose to borrow under joint liability. We therefore estimate the effect of joint liability on improving repayment rates among those who would choose to borrow under joint liability. While restricting our analysis to this sample may compromise external validity, we believe this is a highly relevant sample: measuring the effect on those who decline to borrow under joint liability would have little relevance for the outside world. Of course, the sample is also selected on individuals who chose to borrow in an individual liability setting. However, given that most theory suggests that joint liability leads to stricter screening and stricter monitoring, this additional screen may not be that restrictive.

While the setting we study may be anomalous in that the typical transition in the microfinance industry at present is the reverse, we believe that carefully studying the effects of shifts in liability, in either direction, is informative and valuable. Indeed, the recent collapse of Banco del Exito (BANEX), one of the largest microlenders in Nicaragua, highlights the importance of examining the relative merits of group liability and individual liability contracts. Furthermore, the main question that we ask - that is, conditional on borrowing, whether liability rules impact repayment performance - is of important policy and theoretic interest, as we consider how joint liability lending may improve on individual liability lending. It is difficult to imagine how any single study could capture both the compositional effects and the effect of contract structure on those who have borrowed in individual and 
joint liability settings.

By focusing on clients who borrowed under both individual and joint liability, our study further highlights the importance of examining the impact of lending contracts on financial inclusion. In the setting we study, almost $80 \%$ of borrowers who completed their individual liability loan and could have borrowed under joint liability did not do so. While this indicates that it is possible for the shift in joint liability to have negative consequences on financial inclusion, we do not have data on why people choose or don't choose to borrow with Saath. On the one hand, many new clients (who had not previously borrowed under individual liability) joined Saath after joint liability may have chosen to stop borrowing for a number of reasons (e.g. no further project/investment needs, shifting business or employment status). Without further data, we cannot determine the impact of joint liability on financial inclusion.

Finally, while we do find strong evidence that joint liability improves upon individual liability lending in terms of repayment behavior, we cannot be certain that the treatment effect would be similar for other MFIs. The MFI we study, Saath, has operations that are fairly typical of small MFIs around the world. But on the other hand, we also evaluate a particular joint liability lending program, wherein borrower groups have a group leader who collects repayment for her group, as opposed to public repayment (e.g. at the village center), which is the collection method that is perhaps more common among other MFIs. In this sense, the external validity of our findings may be limited.

\subsubsection{Data Limitations}

Since the data that are available were used primarily for accounting purposes, the dataset does not contain information on the terms of each loan, such as maturity dates, installments amounts, and outstanding loan amounts, all of which were recorded by loan officers in paper ledgers. Thus, our analysis is limited to observing whether a client made a loan repayment or a compulsory savings deposit for a particular month, and we are unable to look at outcomes

on overdue loan amounts, prepayments, and other measures. Furthermore, aside from data 
on gender and the client's neighborhood, the data does not contain other demographic or household characteristics of clients.

Because of data limitations, our ability to understand why borrowing amounts increase is limited. Under individual liability, borrowers were limited to loan amounts that were a fixed proportion of their savings and their guarantors' savings. These restrictions were removed under joint liability and replaced with a strict appraisal process for group members. Ideally, if we had deposit data under individual liability, we could see exactly whether these borrowing constraints were binding under individual liability. Unfortunately, Saath did not keep good records of this data in the past, hence, it is not possible to statistically distinguish demand and supply effects on loan size.

\subsection{Effect of Lending Structure on Loan Repayment}

We now turn to the critical question of loan repayment. We note that the joint liability structure will in theory induce not only better screening, but also greater monitoring efforts. Our empirical design does not distinguish between the two potential causes of improved repayment, but rather estimates the combined causal effect.

Table 2 presents OLS estimates of Equation 1, where the outcome of interest is a dummy variable for a missed payment. This dummy variable indicates whether the client failed to make a repayment for a particular month. Saath Microfinance clients are required to make monthly repayments until the principal balance is paid in full, beginning 30 days following disbursement. Hence, the dependent variable takes on the value 1 for a particular month if the total amount repaid by the borrower for that month is nil, and 0 otherwise. We use this dummy variable as our first measure of monthly loan repayment discipline.

In our sample, almost $20 \%$ of individual liability and only $0.1 \%$ of group liability monthly loan repayments were not made. Our main results are presented in Table 2, Column (1) presents regression results with no fixed-effects, controlling only for which branch a borrower uses. Taken at face value, group lending reduces the probability of missing a payment by 
17.5 percentage points. In columns (2)-(4), we add individual fixed effects, calendar month fixed effects, and both sets of fixed effects, respectively. Finally, in columns (5) and (6) we add controls for the age of the loan: repayments may be higher early in the cycle, when borrowers are flush with cash, or later in the cycle, when borrowers seek to repay a loan in order to obtain a new one. The coefficient drops, though only coefficients (1) and (6) have 95 percent confidence intervals which (barely) do not overlap. Because only overdue loans last more than 12 months, loan age coefficients may "soak up" some of the treatment effect, particularly when individual and month fixed-effects are present.7]

Our preferred point estimate is column (4), which indicates that group lending reduces the probability of a missed payment by 11.2 percentage points. This is a large and meaningful effect, which could have significant implications for the profitability of a lender.

\subsubsection{Internal Validity}

We conduct a number of robustness tests. First, we report a direct "falsification" test of our analysis by using data from our clients' previous individual-to-individual loan renewals. Specifically, we focus on clients in our sample who had at least two individual liability loans, and the sample is reduced since many clients did not have multiple loans in the past. Among these clients, we study whether borrowing experience with the microlender is related to loan repayment; in other words, whether having a second loan causes borrowers to repay better. Table A.1 presents these results and shows no significant effect on missed payments.8

A second concern with the internal validity of our analysis is the fact that joint liability contracts are a completely new contractual arrangement. In particular, since the arrange-

\footnotetext{
${ }^{7} \mathrm{~A}$ simple way to address the relationship between loan age and repayment status is to to restrict the sample to the first twelve months of repayment data: doing so with the same specifications as reported in Table 2 yields point estimates ranging from -.074 to -.153, statistically indistinguishable from each other, but all statistically different from 0 at the one percent level.

${ }^{8}$ The specific date (November 2007) for the falsification test was not chosen arbitrarily (rather, it was precisely one year prior to the actual change in date), but we have conducted the analysis for all months at least one year before the policy change, and find our effect is dramatically larger than any other date. Specifically, we re-ran our specification with each of the previous twelve months as our placebo date, and found only two cases to be significant, but of much lower magnitude.
} 
ment is new, clients may be in a "honeymoon" period.9 During this period, clients may be on their best repayment behavior while they are learning the rules of the game, but over time, as clients gain a better understanding of the consequences of missing a payment, they may start behaving more strategically. To test for this "honeymoon" effect, we compare the default rates of new clients (i.e. first-time Saath borrowers) under the individual and joint liability regimes over our sample period. Specifically, we find that first-time Saath borrowers make late payments $49 \%$ of the time in the individual liability setting, and $2 \%$ of the time under joint liability. Since we are comparing clients who are borrowing for the first time in either setting, this result suggests that the "honeymoon" effect does not drive repayment behavior of clients.

A third concern is that a client's propensity to repay may be correlated with the time in the loan cycle: specifically, clients may be more likely to make repayments towards the end of their last individual liability cycle, in order to ensure eligibility for a group liability loan in the future. We note that this would bias estimates against finding that group liability improves borrower performance. Nevertheless, we investigate this possibility using an eventtime regression with the dependent variable for missed payment as previously described, where the event is the conversion from an individual liability to a group liability-loan.

Figure A.1 plots the coefficients for each event-time dummy. The first month of repayment in the group liability setting is at time $=0$, the final repayment month in the individual liability loan is at time $=-1$, the second to the last individual liability loan repayment month is at time $=-2$, and so on. Thus, the figure describes loan repayment behavior under the individual liability contract, before switching to group liability. Saath requires its borrowers to pay their current loan in full before they are given their next loan, so by definition, all clients in our sample made a repayment at time $=-1$. Examining the periods where time $\leq-2$ shows no pattern supporting the idea that clients strategically repaid their individual liability loan so that they may borrow under the group liability setting.

\footnotetext{
${ }^{9}$ We thank an anonymous referee for raising this point.
} 
Alternatively, clients may be more likely make repayments early on in the loan cycle, as they may be flush with cash from a recent loan disbursal. We examine this possibility, again using an event-time regression, as shown in Figure A.2. We estimate how repayment rates change around loan renewal times when a client pays off an individual liability loan and renews for another individual liability loan (blue line), and for the cases when a client pays off a group liability loan and renews for a second group liability loan (red line). Note that the first month of repayment in the second loan cycle is at time $=0$, and the final repayment in the first loan cycle is at time $=-1$. Similar to Figure A.1, at time $=-1$, all clients made a repayment by definition, so the missed payment dummy must mechanically equal zero. Figure A.3 shows that prior missed payments are uncorrelated with the number of months since loan origination.

Our study sample consists of individual liability clients who chose to renew their borrowing under the group liability setting. These clients may be better at repayment than borrowers who did not want to enter into a group liability loan contract. However, our analysis focuses exclusively on those who renew and includes individual fixed effects. Hence, an interpretation of our results is that even "good" clients exhibited higher repayment discipline under the group liability setting, in comparison to the individual liability setting. However, we also acknowledge that by focusing only on those clients who borrowed under both types of contracts, we limit the external validity of our results.

The outcome we have considered thus far, whether the client missed a loan installment for a particular month, is a rough measure since repayments may be partial. That is, a client may have repaid an amount greater than zero, but this amount may be less than the required installment amount. Another measure of repayment discipline, then, is the standard deviation of principal amount repaid for individual liability loans and total amount repaid for group liability loans. As described in Section 3, the principal installment amount was fixed in the individual liability setting, whereas in group liability, the required total installment amount (principal plus interest) was equated every month. If the required amount is repaid 
each month, then the standard deviation would be zero. However, if there are many months where people pay less or more than the required amount, then the standard deviation would be higher. Table A.2 provides OLS estimates where the dependent variable is the standard deviation of repayment. Again, our estimates show that there is greater loan repayment discipline in the group liability setting relative to individual liability, although this effect is not statistically significant.

Finally, we note that the average loan size increased from 10,000 INR under individual liability to 18,000 INR under joint liability (see Table 1). This increase is large and warrants further discussion. In some ways, it can be thought of as an effect of the group lending model, as Saath was willing to extend larger loans to borrowers on the strength of social collateral. Indeed, Saath management told us that they were willing to give larger loans precisely because of the joint liability framework.

However, one may reasonably wonder whether the increase in loan size itself affects repayment rates. For example, if borrowers invest in convex production technologies, higher credit limits themselves could increase repayment. We test for this in two ways. First, we split the sample into four quartiles, based on the percentage increase in credit limit a borrower benefited from as she or he converted to joint liability lending. We do not observe systematic variation in the treatment effect estimate along this dimension (results not reported). Second, because our dataset includes the reported purpose of each group liability loan, we can conduct separate analyses for loans taken for the purpose of consumption, productive activities, and asset creation. Again, we find no evidence the treatment effect varies across these three categories (results not reported).

\subsubsection{Discussion}

Given these results, a natural question that arises is why group liability outperforms individual liability for clients who are already borrowing. Although the guarantors requirement in individual liability contracts provided incentives for guarantors to monitor loans and en- 
force repayment, these incentives in practice were quite weak: the microlender rarely seized the savings of guarantors of defaulting clients, and did not strictly enforce that guarantors maintain their savings account balance. The microlender collected repayment from the guarantors only if all other options (e.g. seizing the defaulting borrower's savings, revisiting the defaulting borrower, threatening to charge penalties, rescheduling the loan, having the branch manager intervene) have been exhausted. In contrast, the group liability structure strengthens cooperation and trust among group members, as indicated by the fact that almost all joint liability borrower groups designate a group leader even though it is not required. It is possible that having a group leader increases incentives for monitoring and enforcing repayment. For example, having a group leader perhaps creates a person of authority who can enforce repayment or impose sanctions in the event of default.

We also note that the borrowing requirements for individual liability loans suggest that the effects we find would likely be smaller in magnitude had such requirements not been in place. Since individual liability loan borrowers must have two guarantors and Saath may use guarantors' savings in the event of default, it is possible that these requirements encourage the screening of potential individual liability loan borrowers; we are not able to control for such effects.

\subsection{Savings Discipline}

We now turn our attention to the compulsory savings deposits required by Saath. As discussed in Section 2, we might expect savings to be higher in the joint liability setting, since participating in a borrower group may allow individuals to avoid financial demands from their families, or to overcome self-control problems. Furthermore, compulsory savings is required to continue as a member in good standing with Saath, as those who do not meet the compulsory savings requirements are not allowed to borrow until these requirements have been met. Thus, the same form of peer pressure that applies to loan repayment may apply to compulsory savings as well. 
Although Saath initiated both a shift to group liability lending and compulsory deposits at the same time in November 2007, we can separately identify the effect of group liability on compulsory savings by exploiting the time-series variation in loan renewals. Specifically, while the compulsory savings were mandated across the board for all borrowers postNovember 2007, the shift from individual to group liability was staggered, depending on when each individual loan term expired. As explained earlier, these renewals were distributed relatively uniformly throughout the year, resulting in variation in loan contract at a time where compulsory savings was uniform. Hence, we can study the adherence to compulsory savings for the same person who was borrowing under an individual liability contract post-November 2007 and who eventually converted to a group liability contract:10

Table 3 presents OLS estimates where our dependent variable is a dummy for missing a compulsory savings deposit. The dependent variable takes on the value 1 if the client deposited less then INR 100, and 0 otherwise. The point estimate in column (4), which include month and individual fixed effects, indicates that the same borrower is 20.5 percentage points less likely to miss a compulsory deposit when in a group lending arrangement than when borrowing individually.

This suggests that one possible mechanism through which group liability reduces loan delinquency may be increased savings: a greater savings balance may provide a buffer for borrowers hit with liquidity shocks.

\subsection{Heterogenous Effects}

We test for heterogenous effects along two dimensions. As before, our dependent variable is a dummy for whether a client missed a loan repayment for a particular month. Columns (1)-(3) indicate a significantly larger impact of group liability in reducing missed payments among men, although the effect for females is still negative and significant. It is important to note,

\footnotetext{
${ }^{10}$ Since we only have savings data from January 2008 onwards, we cannot study the effect of compulsory savings under the individual liability setting, as we have no pre-period data (i.e. savings data pre-November 2007).
} 
however, that the control group means for females are also significantly lower, with missed payment rates at 16 percent for females and 23 percent for males 11 The results suggest that group liability effectively neutralizes this gender differential in missed payments.

In columns (4)-(6), we examine whether group lending improves repayment behavior more for clients who initially exhibited poor repayment discipline under individual liability. We define 'borrower quality' as the percentage of missed payments in the client's first individual liability loan in the data, and we split the sample in two along this measure. Note that since our definition of borrower quality makes use of a client's repayment behavior in her first individual loan, the regressions columns (4)-(6) are restricted to the subsample of clients who had at least two individual loans, and include repayment data only from the client's second individual loan onwards.

In terms of past missed payments, we find that group liability has a larger impact on borrowers who, at the outset, were of poor quality: clients who missed 10 percent of their first individual loan monthly payments are 2.4 percent less likely to miss repayments under the group liability regime. Hence, similar to the gender results, the introduction of group liability is effective in reducing missed payments among those with inconsistent payment records.

\section{Discussion and Conclusion}

Microfinance has reached over 150 million borrowers worldwide and is growing at a 40 percent cumulative average growth rate. Recent initial public offerings (IPOs) which valued the Mexican microfinance institution Compartamos at $\$ 2$ billion, and SKS in India at $\$ 1.5$ billion, have attracted the attention of global financial markets. Yet, there have also been spectacular failures, such as the collapse of Banco del Exito (BANEX), which with a $\$ 125$ million dollar loan portfolio was recently the largest micro and small and medium enterprise lender in Nicaragua. Suffering from a 45 percent delinquency rate, it was ordered into

\footnotetext{
${ }^{11} \mathrm{~A}$ difference in means test is significant at the 1 percent level.
} 
liquidation 12

As many microlenders around the world weaken their group liability approach and shift towards individual lending, understanding the role of group liability in enhancing performance has become a critical question in microfinance programs, moving forward. Yet, the empirical literature provides little guidance for policy makers and microfinance practitioners, since few empirical studies have examined group liability contracts with other lending strategies.

In this paper, we exploit an exogenous change in liability structure in an Indian microfinance program, where the program shifted from individual liability to a group liability structure. We find evidence that for the same borrower, the shift to group liability reduces default rates and improves savings discipline. Under the group liability setting, required monthly loan installments are $11 \%$ less likely to be missed and compulsory savings deposits are about $20 \%$ less likely to be missed, relative to individual liability. Thus, our findings indicate that group lending outperforms individual lending in loan repayment and savings discipline.

We see our study as an important piece of evidence, rather than a definitive answer to the question of optimal lending structure for microfinance. The microlender we study, Saath, has operations that are fairly typical of MFIs that lend in urban areas. Moreover, the management, infrastructure, and stated goals of Saath are not markedly different from lenders throughout India, or other MFIs in low-income settings. Saath's most remarkable characteristic is probably its small size, as the microfinance industry includes an important right tail of very large lenders. Yet, small institutions like Saath (an NGO with \$410,000 dollars in total loan portfolio as of 2009) make up a non-trivial portion of the industry.

Second, as with any natural experiment, we caution that there are limitations to our study: our sample consists of only those who elected to continue from the individual to group lending model and thus may not be representative of the entire population that would

\footnotetext{
${ }^{12}$ See: http://financialaccess.org/node/3547
} 
be effected by changes in lending models; we are unable to clearly identify the mechanisms through which group lending improves repayment; and our data are not sufficient to allow us to precisely calculate the effect of lending structure change on lender profitability. An ideal experiment to answer these questions might have randomly assigned individuals to a range of different lending models, such as group lending with self-selected group members, group lending with randomly assigned group members, and group lending without group liability.

It may be nevertheless useful to discuss our view of the mechanisms at work, based on our reading of the evidence, and on numerous conversations with Saath clients, staff, and management. We think peer pressure is important. The Saath operations manual itself stated, "The concept of peer pressure must be executed properly in favor of the organization and concept of micro finance," arguing that the group leader should take responsibility for ensuring members repay, and stressing the importance of joint liability. In case of repeated missed payments, the manual instructed staff to ensure "the members take the responsibility of closing the loan amount of" a delinquent borrower. We also interviewed 10 Saath field officers about how the loan collection process changed with group lending. All ten field officers mentioned that collection under joint liability was easier, because clients were more disciplined about paying on time, and several others mentioned the importance of "collective responsibility" within the group. These qualitative reports are consistent with a recent paper on microfinance in Andhra Pradesh, which finds that peer pressure was an important determinant of loan repayment (see Breza (2012)).

Taken in their whole, we believe our results should provide a cautionary tale for policymakers and microfinance institutions eager to convert from group to individual lending models. While most microfinance organizations around the world have reported repayment rates that are impressively high, the industry has also witnessed both idiosyncratic failure and more widespread collapse, such as the recent crisis in Andhra Pradesh. Our results highlight the importance of the group lending structure in facilitating sustainable provision of credit to the poor. Our findings suggest a need for further research, to identify the precise mech- 
anisms of how joint liability affects borrower behavior, the role of savings as a mechanism for improving repayment, and the relative merits of peer screening versus peer monitoring under group liability contracts. Finally, it would be useful to understand whether the group lending structure itself could be improved upon, perhaps by introducing some formal group or sub-group level repayment incentives or insurance mechanisms.

\section{References}

Ahlin, C., Townsend, R. M., February 2007. Using repayment data to test across models of joint liability lending. The Economic Journal 117 (517), F11-F51.

Ambec, S., Treich, N., 2007. Roscas as financial agreements to cope with self-control problems. Journal of Development Economics 82 (1), 120-137.

Armendáriz de Aghion, B., 1999. On the design of a credit agreement with peer monitoring. Journal of Development Economics 60 (1), 79-104.

Armendáriz de Aghion, B., Morduch, J., 2010. The Economics of Microfinance. MIT Press.

Ashraf, N., Karlan, D., Yin, W., March 2010. Female empowerment: Further evidence from a commitment savings product in the philippines. World Development 38 (3), 333-344.

Atkinson, J., de Janvry, A., McIntosh, C., Sadoulet, E., 2010. Creating incentives to save among microfinance borrowers: A behavioral experiment from guatemala. Working paper.

Attanasio, O., Augsburg, B., Haas, R. D., Fitzimons, E., Harmgart, H., 2011. Group lending or individual lending? evidence from a randomized field experiment in mongolia. IFS Working Paper No. W11/20.

Banerjee, A., Besley, T., Guinnane, T., 1994. Thy neighbor's keeper: The design of a credit cooperative with theory and a test. Quarterly Journal of Economics 109 (2), 491-515. 
Banerjee, A., Duflo, E., Glennerster, R., Kinnan, C., 2009. The miracle of microfinance? Evidence from a randomized evaluation. Department of Economics, Massachusetts Institute of Technology (MIT) Working Paper.

Banerjee, A., Mullainathan, S., 2010. The shape of temptation: Impications for the economic lives of the poor. Working paper.

Banerjee, A. V., Newman, A. F., April 1993. Occupational choice and the process of development. Journal of Political Economy 101 (2), 274-98.

Beck, T., Demirgüç-Kunt, A., Maksimovic, V., 2005. Financial and legal constraints to growth: Does firm size matter? The Journal of Finance 60 (1), 137-177.

Beck, T., Demirgüç-Kunt, A., Martinez-Peria, M. S., 2007. Reaching out: Access to and use of banking services across countries. Journal of Financial Economics 85 (1), 234-266.

Besley, T., Coate, S., 1995. Group lending, repayment incentives and social collateral. Journal of Development Economics 46 (1), 1-18.

Bouman, F. J. A., 1995. Rotating and accumulating savings and credit associations: A development perspective. World Development 23, 371-384.

Breza, E., 2012. Peer effects and loan repayment: Evidence from the krishna default crisis. Working Paper.

Cetorelli, N., Gambera, M., 2001. Banking market structure, financial dependence and growth: International evidence from industry data. The Journal of Finance 56 (2), 617648.

Chen, G., Rasmussen, S., Reille, X., February 2010. Growth and vulnerabilities in microfinance. CGAP Focus Note No. 61.

Daley-Harris, S., 2009. State of the Microcredit Summit Campaign Report 2009. Washington, DC: Microcredit Summit Campaign. 
Feigenberg, B., Field, E., Pande, R., 2010. Building social capital through microfinance. NBER Working Paper No. 16018.

Fischer, G., 2010. Contract structure, risk sharing and investment choice. LSE Working Paper No. EOPP/2011/23.

Ghatak, M., 2000. Screening by the company you keep: Joint liability lending and the peer selection effect. Economic Journal 110 (465), 601-31.

Giné, X., Karlan, D., November 2009. Group versus individual liability: Long term evidence from philippine microcredit lending groups. Working Paper.

Gugerty, M. K., January 2007. You can't save alone: Commitment in rotating savings and credit associations in kenya. Economic Development and Cultural Change 55 (2), 251-282.

Laibson, D., 1997. Golden eggs and hyperbolic discounting. Quarterly Journal of Economics $112,443-477$.

Morduch, J., December 1999. The microfinance promise. Journal of Economic Literature XXXVII (4), 1569-1614.

Rajan, R., Zingales, L., 1998. Financial dependence and growth. American Economic Review $88(3), 559-586$.

Sharma, M., Zeller, M., 1997. Repayment performance in group-based credit programs in bangladesh: An empirical analysis. World Development 25 (10), 1731-42.

Stiglitz, J. E., 1990. Peer monitoring and credit markets. World Bank Economic Review $4(3), 351-366$.

World Bank, 2008. Finance for All? Policies and Pitfalls in Expanding Access. World Bank: Washington, DC. 


\section{Funding}

This work was supported by the World Bank Gender Action Plan; and the HBS Division of Faculty Research and Development to S.C.

\section{Acknowledgements}

This project is a collaborative research effort with Saath Microfinance. We thank Saath, Xavier Giné, David McKenzie, Petia Topalova, and workshop participants at the World Bank for helpful comments and suggestions. Stuti Tripathi and the Center for Microfinance at IFMR provided excellent research assistance. F.C. acknowledges support from the NSF Graduate Research Fellowship Program. 
Table 1: Summary Statistics

This table reports summary statistics for borrowers in our sample. These borrowers received both individual liability and group liability loans.

\begin{tabular}{|c|c|c|c|c|c|c|}
\hline \multirow[b]{2}{*}{ Branch } & \multirow[b]{2}{*}{$\begin{array}{l}\text { Total No. } \\
\text { of Clients }\end{array}$} & \multirow[b]{2}{*}{$\begin{array}{l}\text { Total No. } \\
\text { of Loans }\end{array}$} & \multicolumn{2}{|c|}{ Individual Liability } & \multicolumn{2}{|c|}{ Group Liability } \\
\hline & & & $\begin{array}{l}\text { No. of } \\
\text { Loans }\end{array}$ & $\begin{array}{l}\text { Ave. Loan } \\
\text { Amt (Rs.) }\end{array}$ & $\begin{array}{l}\text { No. of } \\
\text { Loans }\end{array}$ & $\begin{array}{l}\text { Ave. Loan } \\
\text { Amt (Rs.) }\end{array}$ \\
\hline Behrampura & 198 & 512 & 303 & 9981.1 & 209 & 19081.34 \\
\hline Vasna & 78 & 236 & 147 & 9927.211 & 89 & 16764.04 \\
\hline Full Sample & 276 & 748 & 450 & 9963.014 & 298 & 18389.26 \\
\hline
\end{tabular}




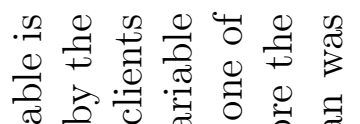

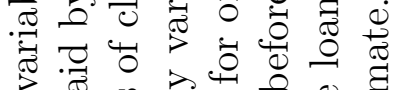

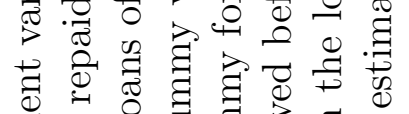

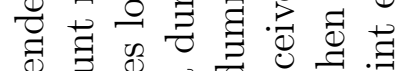

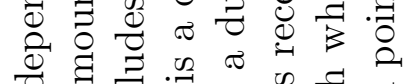

元

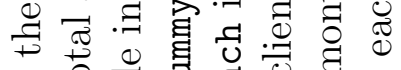

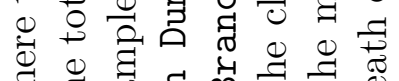

过类

¿

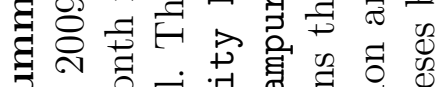

ڤే

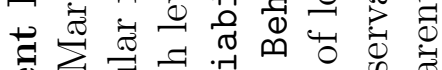

巳

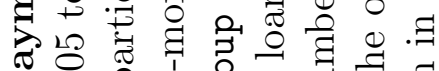

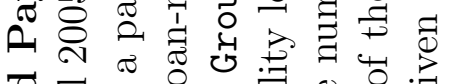

ग $=0.700$

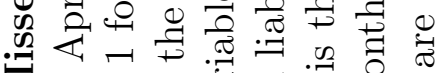

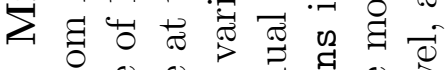

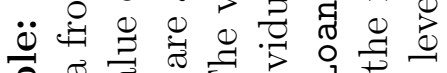

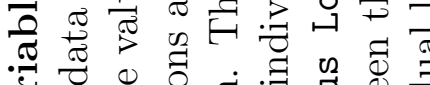

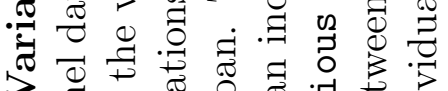

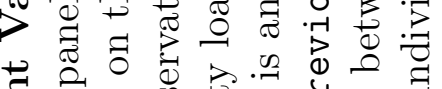

过 2000.

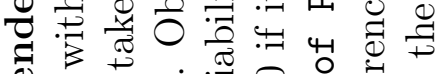

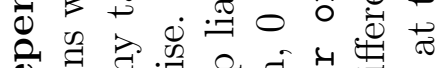

ค.

ง

인

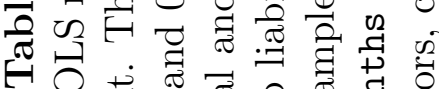

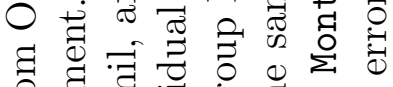

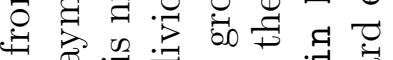

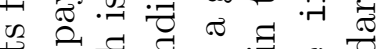

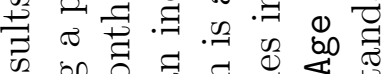

की

击

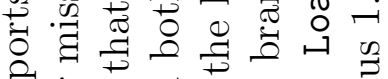

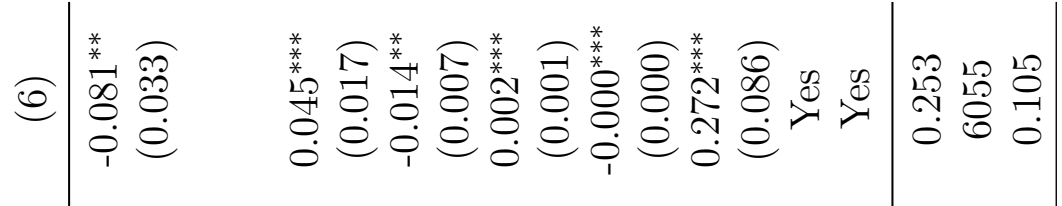

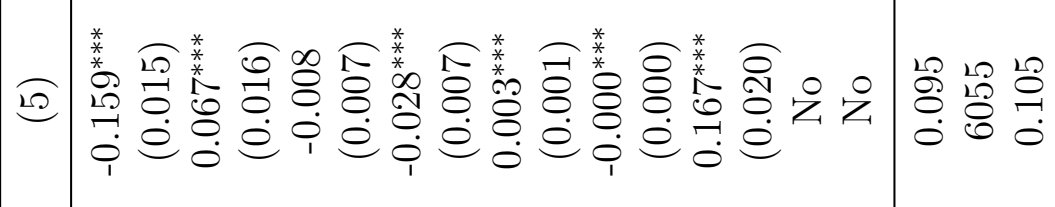

Æ $\stackrel{*}{\stackrel{*}{*}} \overparen{8}$

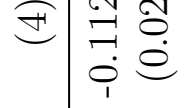

กิ $\stackrel{*}{*}$ กิ

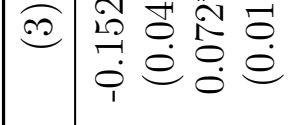

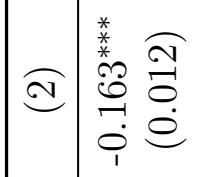

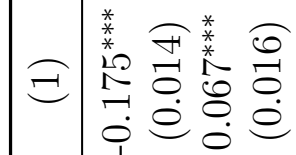

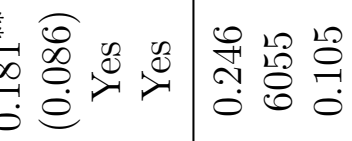

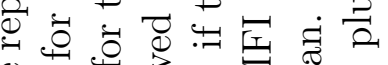

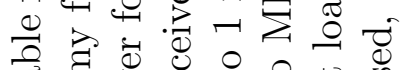

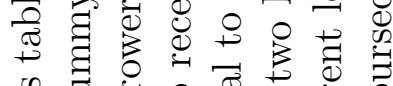

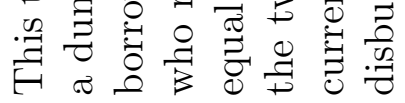

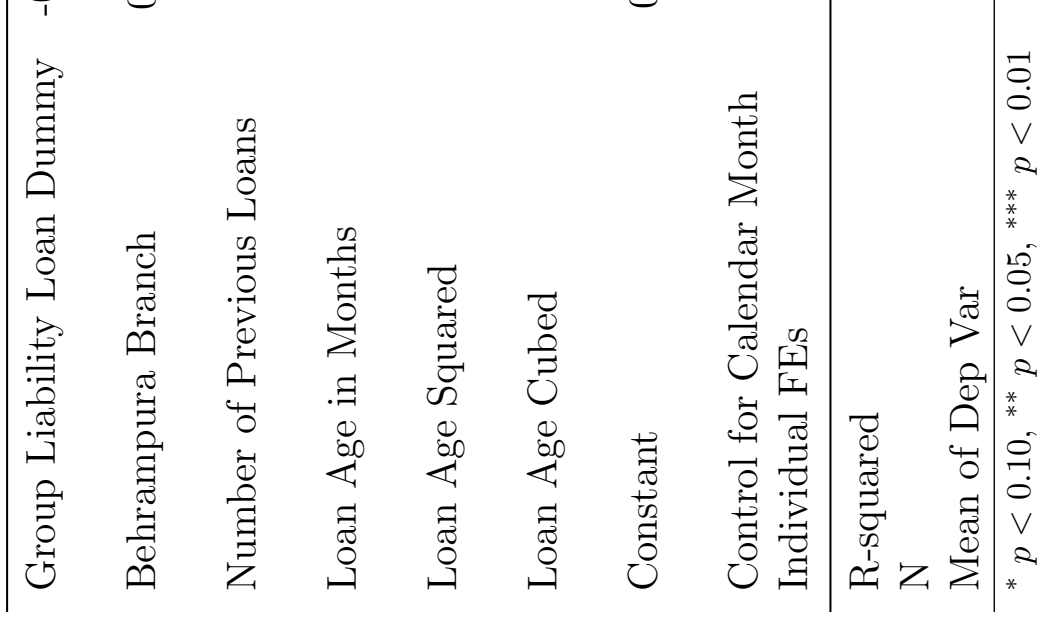




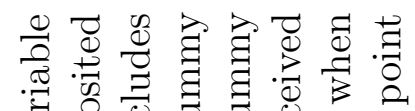

సี.

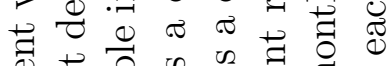

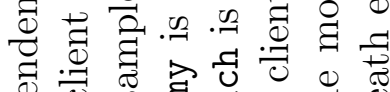

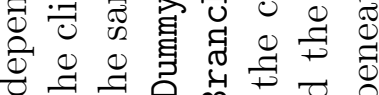

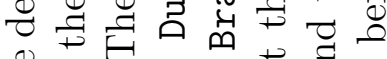

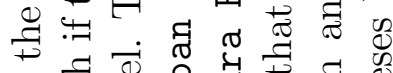

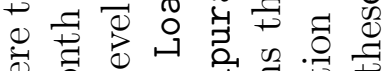

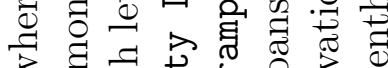

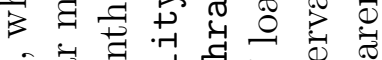

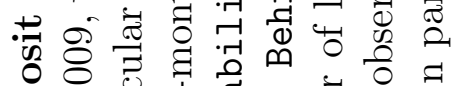

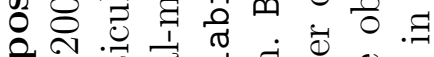

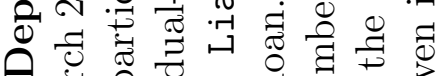

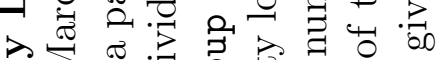

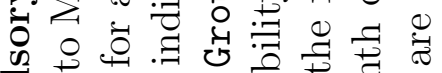

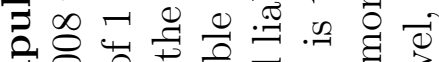

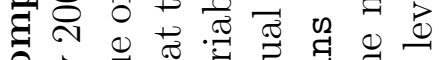

ర

ర

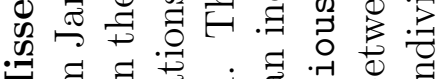

语

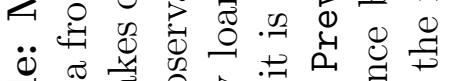

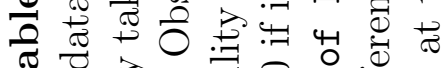

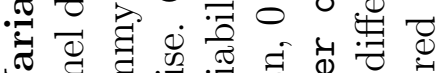

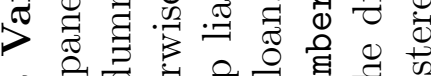

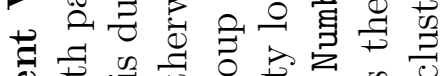

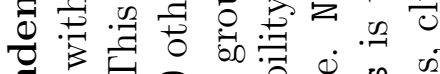
ठํ.

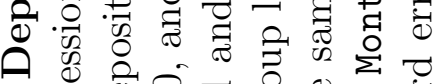
๓

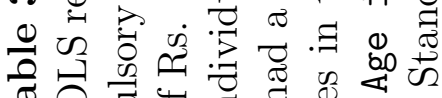
है

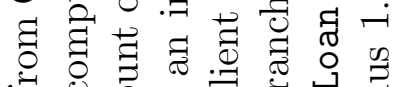

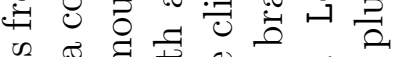
范 ⿹

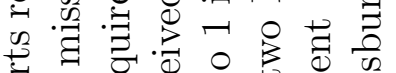
०.

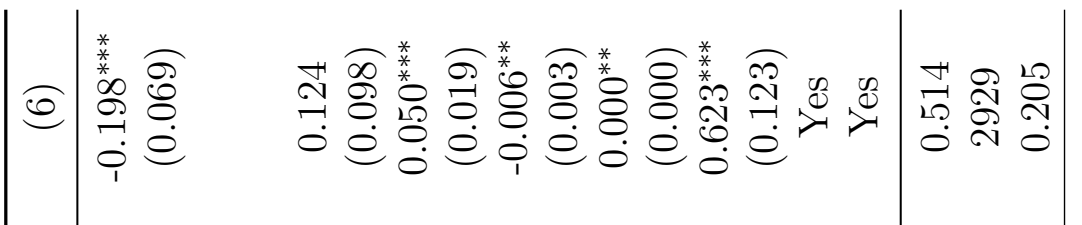

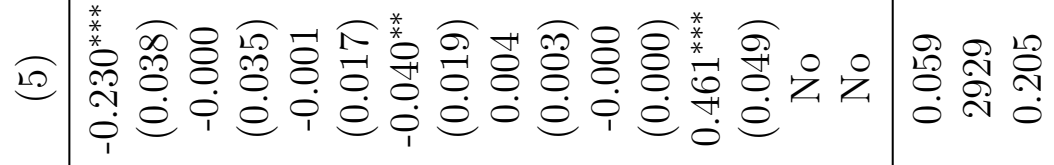

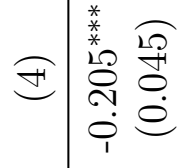

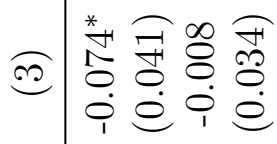

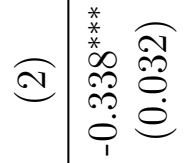

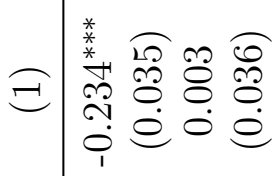

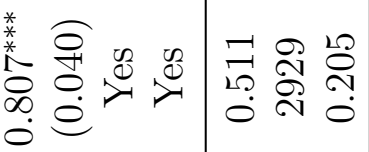

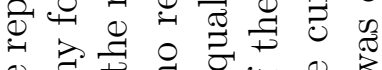

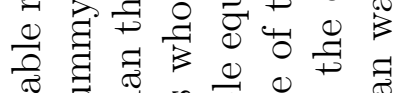

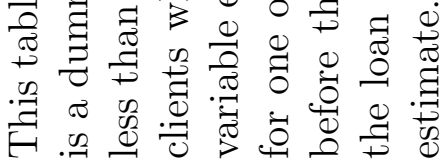

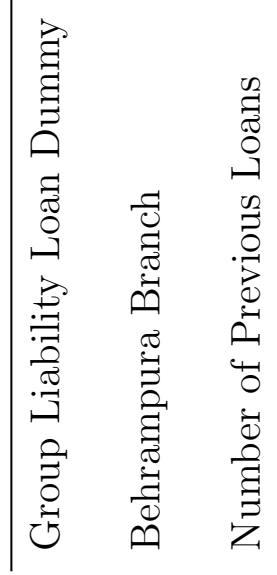

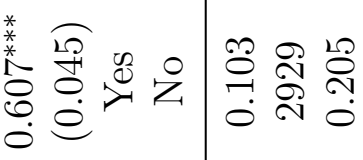

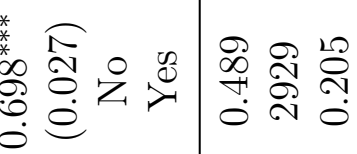

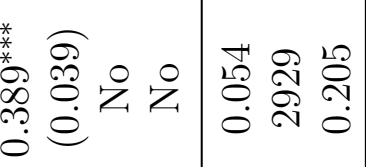

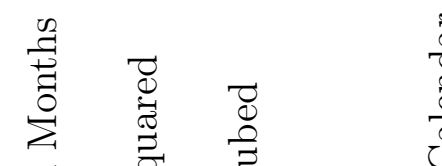






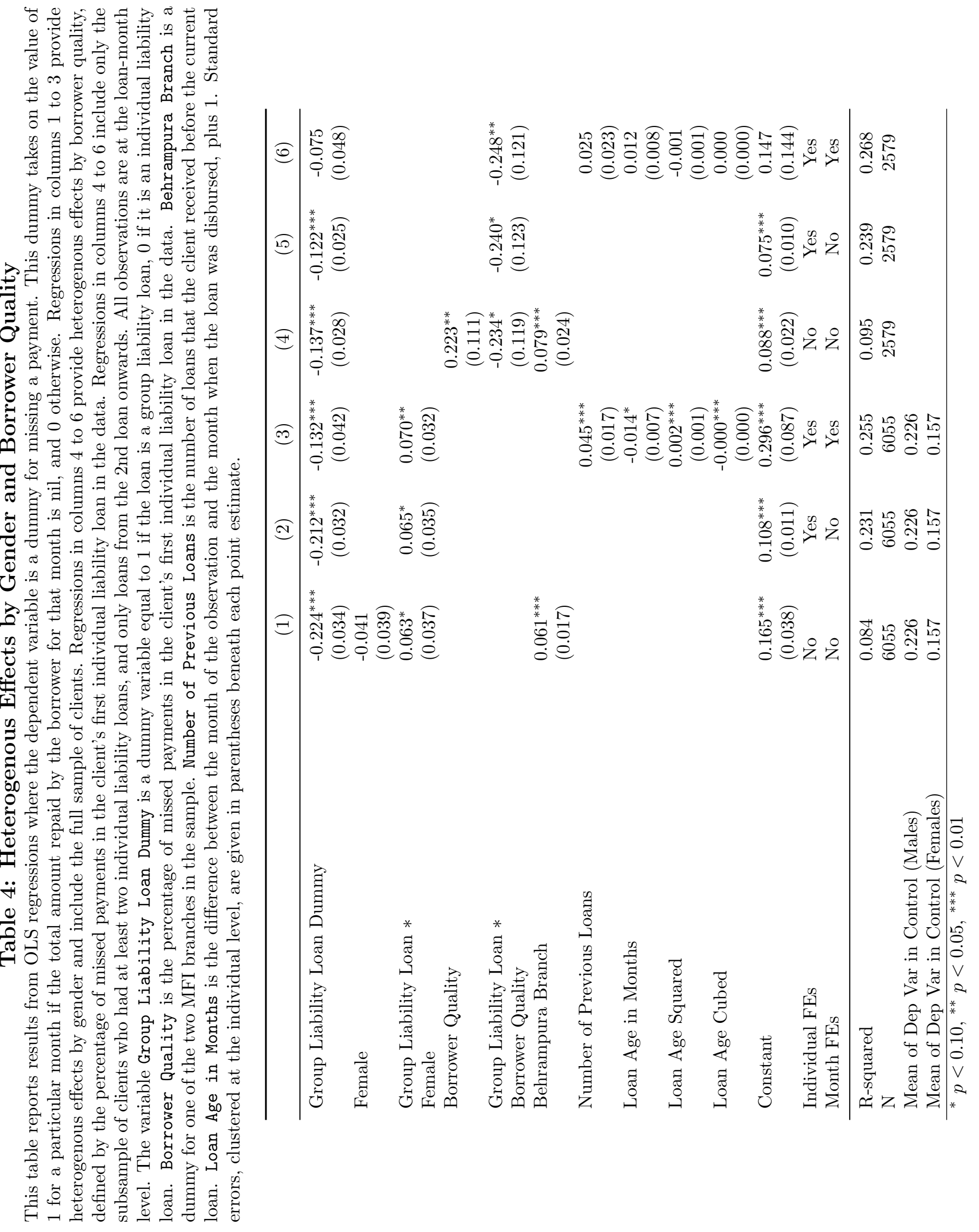


Figure 1: Group Liability Loans Disbursement in Sample

This figure plots the number of group liability loans that are disbursed over time in our sample. All borrowers are previously individual liability borrowers, who subsequently received a group liability loan after the policy change.

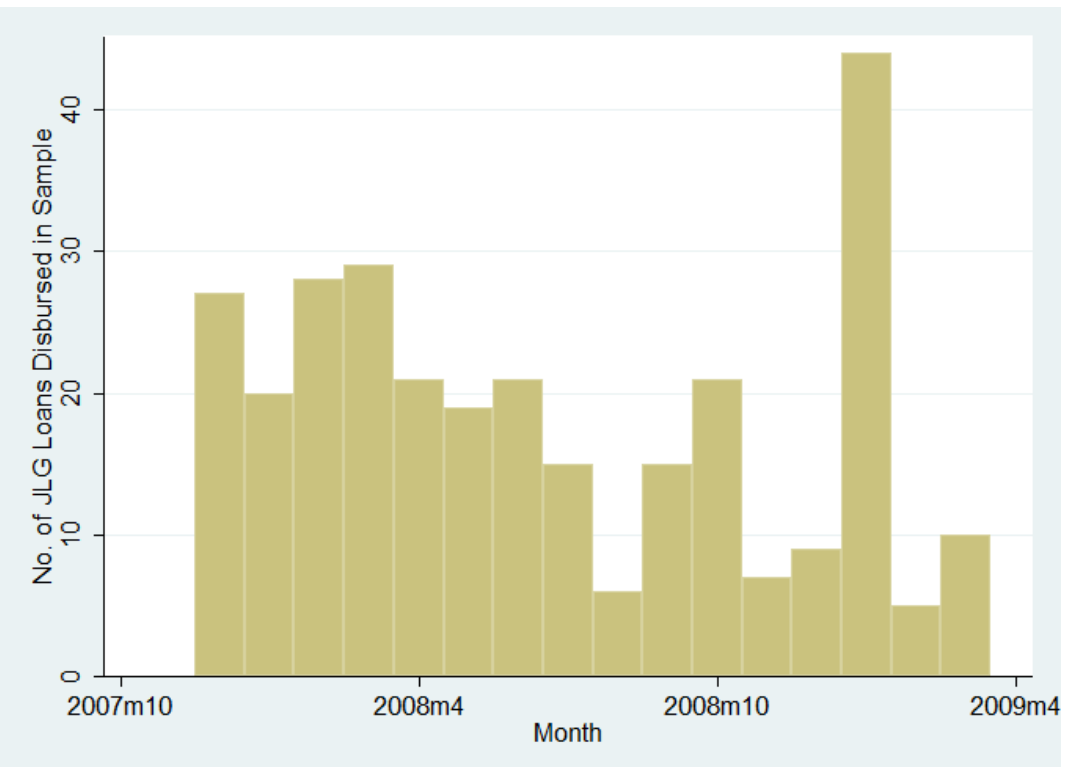




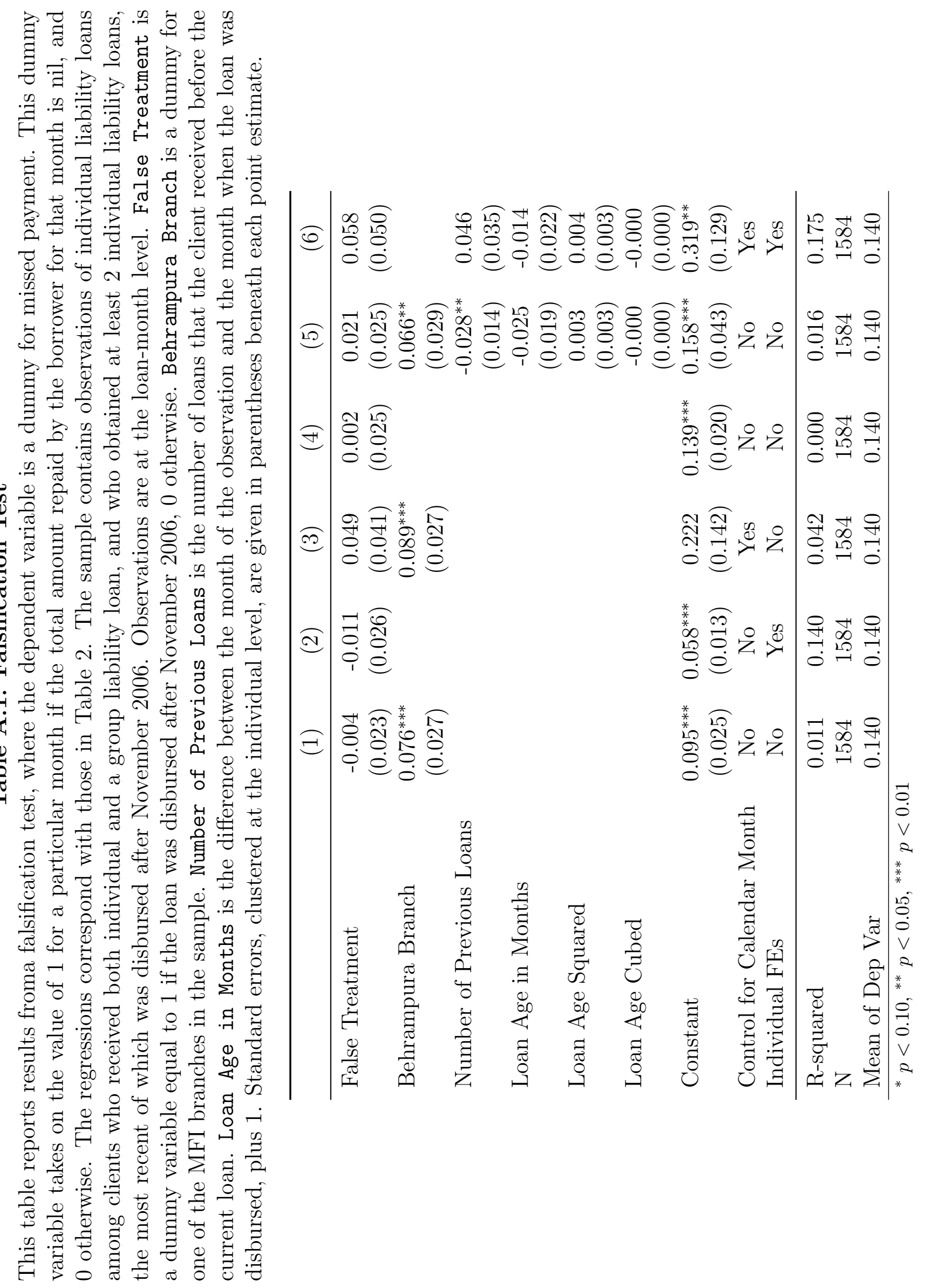




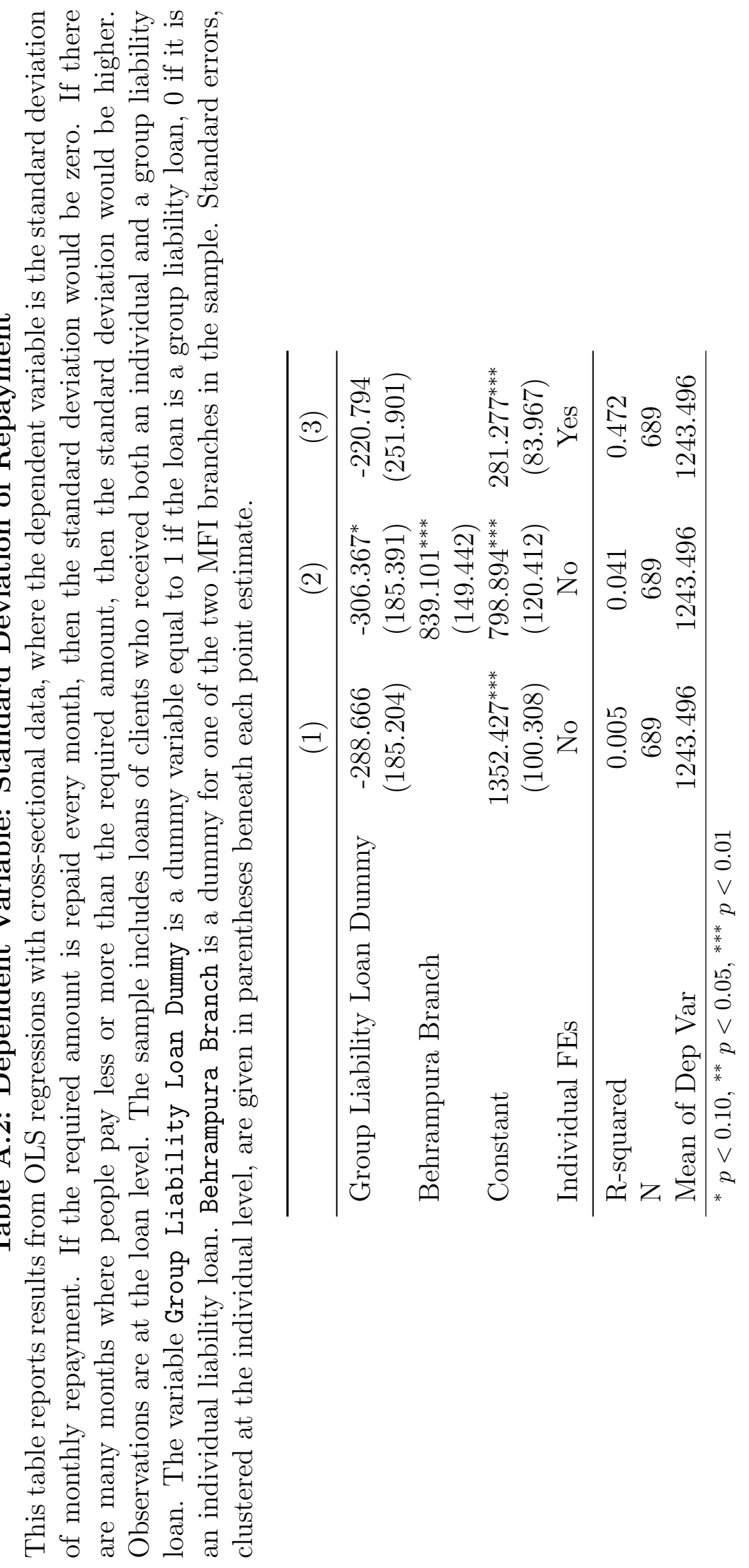


Figure A.1: Event Time Regression: Missed Payment on

Event Time Dummies of Switching from Individual to Group Liability Loan This figure plots coefficients for event-time dummies where the event is the conversion from individual liability to a group liability loan. The dependent variable is a dummy for missing a monthly repayment, which takes on the value 1 for a particular month if the total amount repaid by the borrower for that month is nil, and 0 otherwise. The first month of repayment in the group liability setting is at time $=0$, the final repayment month in the individual liability setting is at time $=-1$. The dashed lines indicate the $95 \%$ confidence interval.

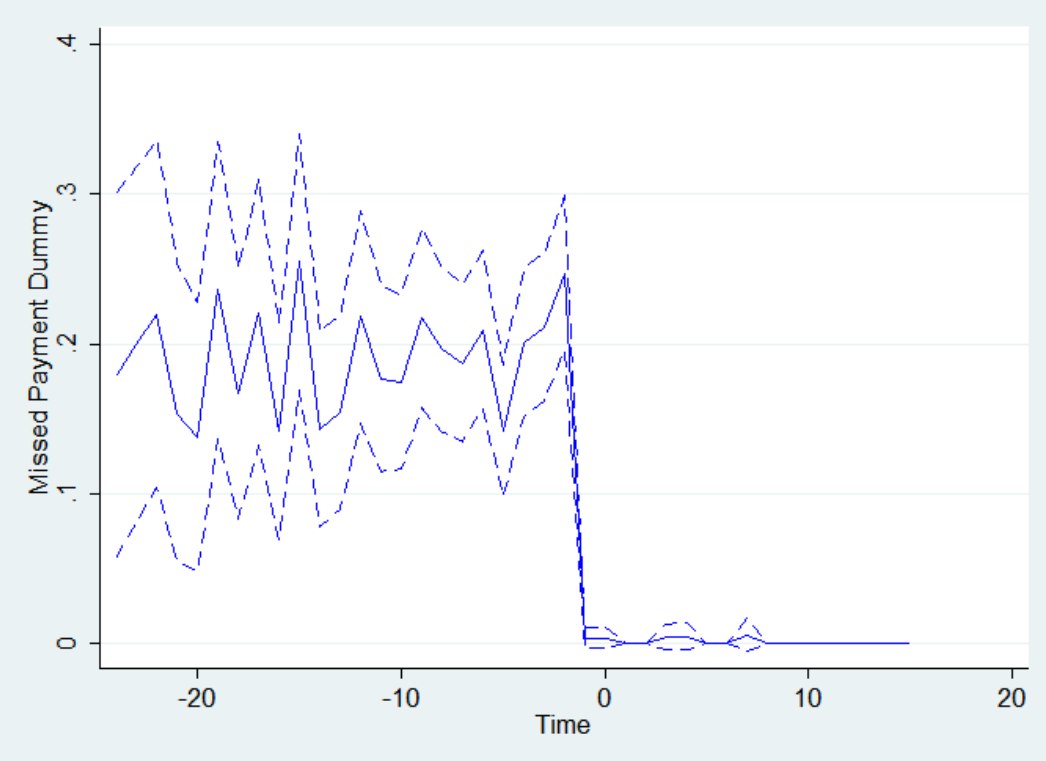

(a) No Controls



(b) With Month FEs 
Figure A.2: Event Time Regression: Missed Payment on Event Time Dummies of Switching from the First to the Second Loan Cycle This figure plots coefficients for event-time dummies where the event is the shift from the client's first loan cycle to the second loan cycle, for each of the individual and group liability loans. The dependent variable is a dummy for missing a monthly repayment, which takes on the value 1 for a particular month if the total amount repaid by the borrower for that month is nil, and 0 otherwise. The first month of repayment in the second loan cycle is at time $=0$, the final repayment month in the first loan cycle is at time $=-1$. The dashed lines indicate the $95 \%$ confidence interval.

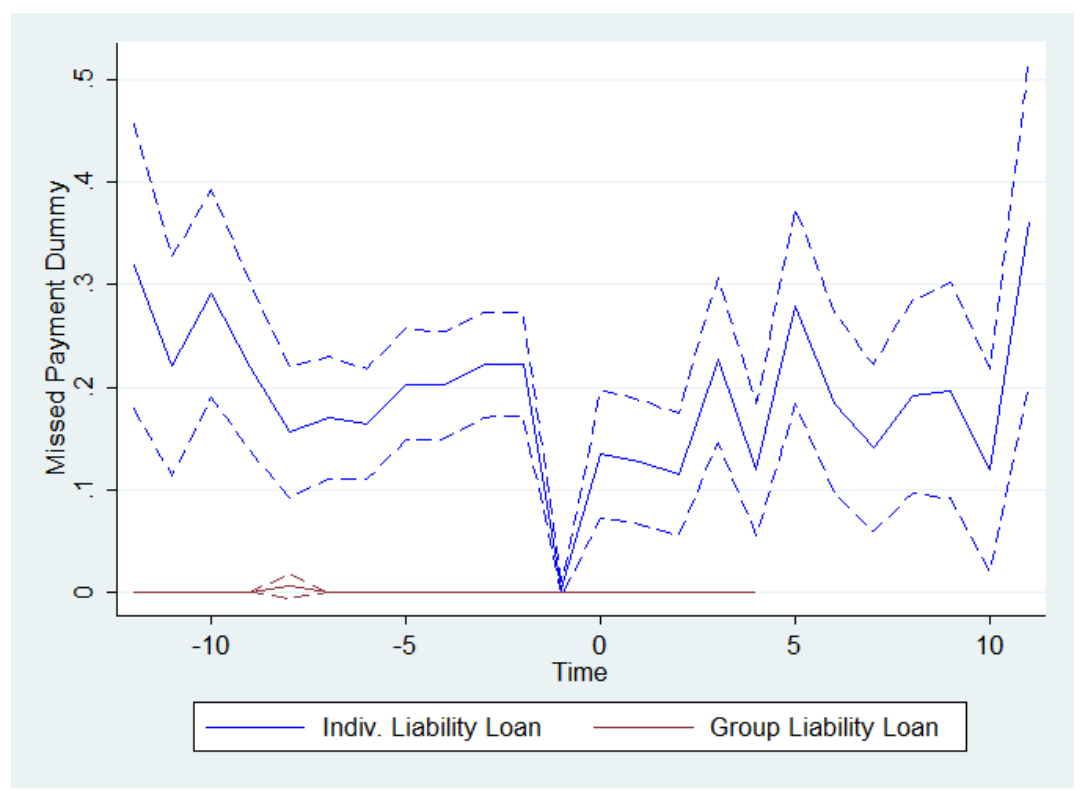

(a) No Controls

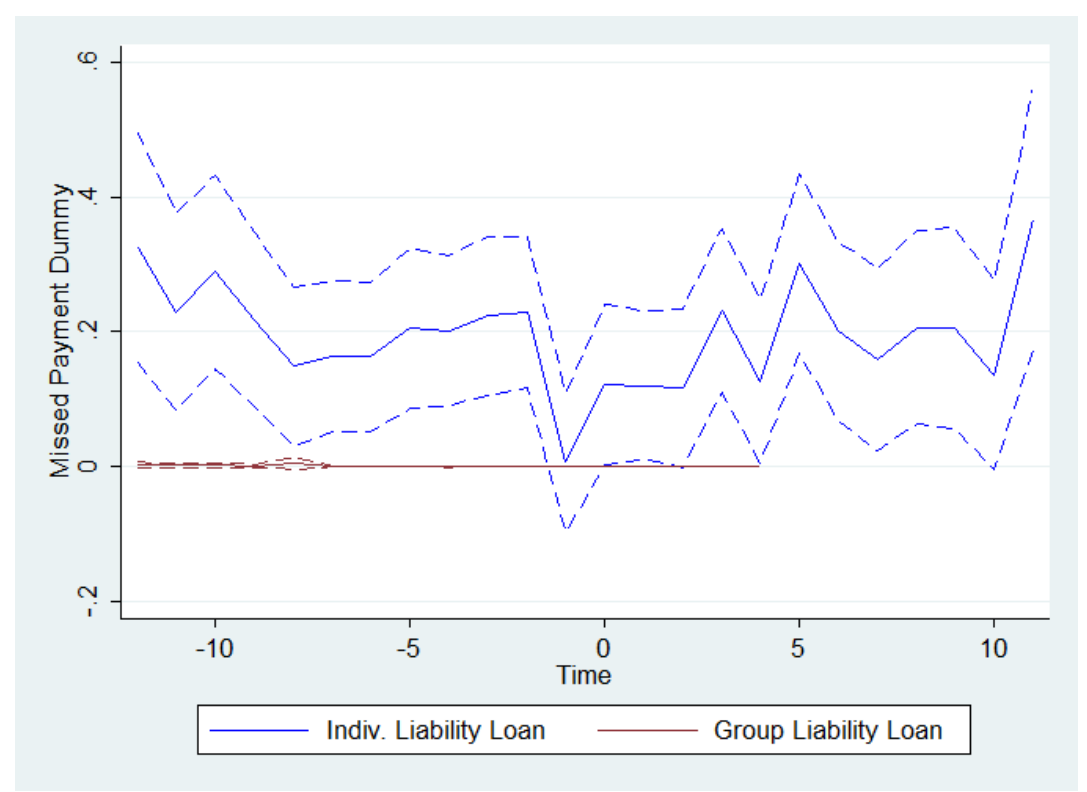

(b) With Month FEs 
Figure A.3: Calendar Month of Loan Origination and Missed Payments This figure plots the percentage of monthly repayments that were missed, using the first three repayments from loan disbursement of the client's most recent individual liability loan. The calendar month of loan origination refers to the calendar month when the loan was disbursed. The size of the bubbles represent frequencies. The red line represents the best-fit line. The sample includes clients who received both an individual and a group liability loan.

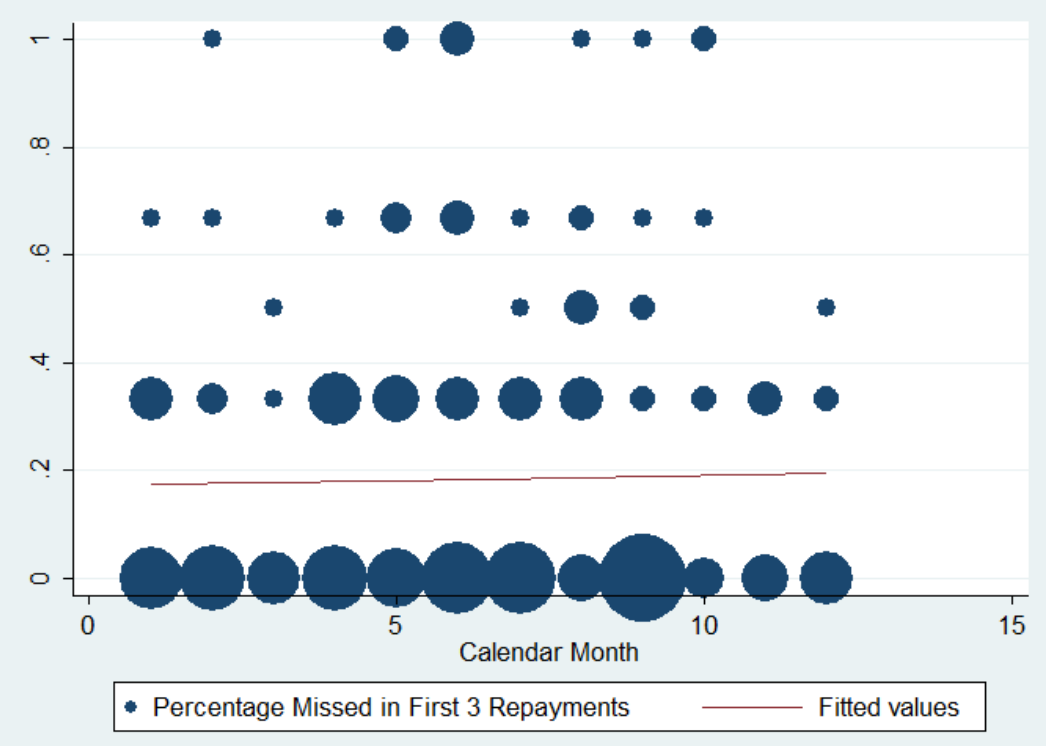

